\title{
我が国における建物の自然換気及び通風に関する研究の 130 年の歴史 130 YEAR HISTORY OF BUILDING NATURAL VENTILATION RESEARCH IN JAPAN - A NARRATIVE REVIEW
}

\author{
小林 知広*1
}

\author{
Tomohiro KOBAYASHI
}

\begin{abstract}
This article gives a brief history of building natural ventilation research over 130 years in J apan based on the author's perspective, aiming to provide a background for researchers in this field. The scientific research on ventilation was first seen in the 1880s and it had been studied mainly in the field of public health research until the 1920s. Many works came to be seen in the architectural engineering afterward, and it is nowadays regarded as a mature research field. The article concludes with an interpretation of the meanings and importance of the research works conducted in such a well-developed field.
\end{abstract}

Keywords : Building Ventilation, Natural Ventilation, Cross-Ventilation, Indoor Air Quality 建物換気, 自然換気, 通風, 室内空気質

\section{1. はじめに : 本論文の主旨と目的}

我が国の建築では古来より風通しが重視され、自然換気や通風に 関わる日本の技術は諸外国と比較しても高水準と言える。学術研 究についても我が国の換気分野は比較的長い歴史を有しており、当 初は建物の気密性能の概念は希薄であった一方で、自然換気や通風 については当学会論文集においても研究発表が戦前から多く見られ る。特に戦後は学会としての組織的な活動により換気設計法等に関 する知見を体系的にまとめてきた歷史的経緯がある。日本の換気研 究は必要に応じて海外からの知見を導入して進化してきた面もある が、建築工学における一分野として長きに渡り取り組まれ、国内の 社会的背景や問題に対応する形で発展した歴史も有している。この 点は我が国の特色の一つとも考えられ、このために建築計画とも密 接に関わる自然換気や通風の研究は欧米諸国と比べても精力的に進 められてきた。現在、我が国の換気研究は既に一定の成熟を見せた 研究分野との認識を持たれることが少なくない 11 。当該分野の研究の 発展に関して明治期や大正期にまで遡って紹介している文献はこれ までにも複数見られるが ${ }^{2-4)}$ 、近年までの換気研究の歴史経緯を体系 的にまとめた研究はあまり多くは見られない。このため、既に膨大 な研究がなされてはいるものの、俯瞰的視野からの整理に欠けてい る面がある。したがって、現代においても残されている課題や今後 新たに取り組むべき問題を見つけることが容易ではなく、当該分野 の研究者の間で問題意識の共有も十分に図られているとは言い難い。 そこで、本論文ではそのような比較的長い歴史を有する換気研究分 野のうちの自然換気に関する研究に主眼を置き、その生い立ちを振 り返る文献調査研究を行い、当該分野の発展の経緯を整理する。そ れにより、発展の過程で問題が認識されながらも放置されている問
題や今後新たに取り組むべき課題を明らかにすることを目的とする。 これにより当該分野の研究者が分野全体を俯瞰して今後求められる 研究の方針を考えるための一助となると考える。

\section{2. 近代日本における換気研究の始まりから基本体系の成熟まで 2.1 我が国の本格的な換気研究はいつ始まったのか}

日本の換気研究は衛生学としての造家衛生・建築衛生がその原点 の一つと言える。例えば、衛生学者としての森林太郎は「陸軍衞生

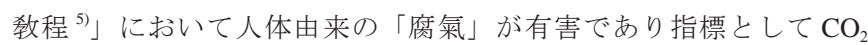
でその室内恕限度の目安を $600 \sim 700 \mathrm{ppm}$ と記している。また、当 学会の前身である造家学会の講演 ${ }^{6)}$ では、特に太陽光と新鮮外気の 適切な取り入れが重要性と強調し、法整備がなされていない明治期 において将来的には法律により建物内の衛生環境を確保する必要が あると警鐘を鳴らしている。

換気に焦点を絞った本格的な学術研究も明治期に見られ始めてお り、筆者の知る限り最も古いものとして、薬学者の田原良純 ${ }^{71}$ や衛 生学者の坪井次郎 ${ }^{8)}$ が大日本私立衛生会雑誌で換気量測定結果を報 告している。田原 ${ }^{71}$ は明治 17 年、換気通風分野は当時研究はおろか その必要性や経験的な方法論すら浸透していない点を問題視した上 で、東京府下の小学校で減衰法によるトレーサーガス実験を行い、 Seidel 式により換気量推定を行なっている。そこで基準としての室内 $\mathrm{CO}_{2}$ 濃度 $1,000 \mathrm{ppm}$ を満たすためには換気量が圧倒的に不足している と示している。併せて、CO 2 はそれ自体が当該濃度で有害ではなく、 あくまで主な発生源が人体である際の基準としての 1,000 ppm の提唱 であると述心、その本質を正しく記している。なお、結言では換気 により健康を保全することで「無限ノ活動力ヨ振起シ富國強兵ノ大 
体ヨ建ツルニ至ラン」と述べられており、時代背景により掲げられ る目的は異なるものの、実験内容や研究の本質が 130 年以上経過し た現代と全く変わらない点も見て取ることができる。

坪井 ${ }^{8)}$ も明治 19 年の「日本家屋換氣論」で $\mathrm{CO}_{2}$ を用いたトレー サーガス減衰法による換気量測定を 15 回にわたり実施している。比 較的詳しく記された坪井の報告からは実験手法に明るかったと推察 されるが、当時所属した帝國大学醫科大学衛生学教室教授の緒方正 規がドイツでPettenkoferに師事した経歴を有したことが影響したと 思わる。なお、坪井自身もこの 4 年後に留学して同氏に師事しており、 日本の本格的な換気研究は、緒方や森、そして坪井らを先駆として ドイツの衛生学を我が国に導入したことがその一つの起源と言える。

\section{2 大正期までの衛生学としての研究と建築学における取り組み}

その他に明治時代に換気に焦点を当てた実験研究は筆者の知る限 りはあまり多くはないが、建築分野では例えば日本土木会社の田中 豊輔 ${ }^{9)}$ が小学校を取り上げ、当時外観が重視され「造家物理」が軽 んじられていることを問題視して、田原 ${ }^{7}$ 同様学校換気の重要性を 述へ、実務の立場から換気筒の計画法を紹介している。大正時代に 入って 6 年の 1917 年には愋房冷蔵協会が設立し、10 年後の昭和 2 年 には衞生工業協会と改称し、会誌「煖房冷蔵協会誌」と「衞生工業 協会誌」を発刊している。他にも同時期に雑誌「國民衛生」が発刊 され、そこで換気通風研究が多く見られ始める ${ }^{10-14)}$

雑誌「國民衛生」は、前述の坪井が創設に携わり初代醫科大學長 を務めた京都帝國大学の衛生学教室から大正 12 年に戸田正三を中心 に創刊された学術誌であり、明治期からは一歩進んで風圧による換 気量や室内風速算定の試みも見られるようになった。この時期には 空気質に着目した換気研究だけでなく温冷感への寄与も含めた気流 評価のための研究も見られ、換気分野の発展において担った役割は 大きい。なお、大正 9 年に設立した同大建築学科に招聘された藤井 厚二の博士論文も同誌に掲載されており、住宅建築の改善に関する 内容を広く扱っている。藤井はその中で夏季の夜間換気の推奨や空 や扉のみならず意図的に換気口を設ける必要性も述べ、実験住宅に よる検証を行なっている ${ }^{15)}$ 。建築設備分野に目を向けると、例えば 柳町政之助が大正 11 年に著した書籍 ${ }^{16)}$ でも必要換気量の計算法が明 記されており、田原 ${ }^{71}$ や坪井 ${ }^{81}$ が論文中で訴えた必要換気量確保の 概念がこの時期には実務の設計でも広まり定着していることがわか る。併せて室用途毎の換気回数の目安も示されており、設備設計と しての換気の考え方もこの時期にはその骨子が形成されている。

\section{3 昭和期の発展から計画原論としてのまとまり}

昭和に入って 5 年、建築学会から各種パンフレットが出版される 中で、關藤國助 ${ }^{17)}$ が「換氣と涼房」を著している。ここでは用途ご との必要換気量や米国の換気基準にも言及した上で、Willis Carrierに よる空調設計の考え方も紹介している。このため、建築の機械設備 的な観点からの空調換気設計パンフレットとも言えるが、この段階 では学会として換気研究の知見を体系的にまとめた位置付けの出版 物とは言い難い。その後昭和 11 年の 3 月には建築学会が論文集を創 刊し、計画原論分野で換気研究が多く見られるようになった。これ 以降、医学的な衛生学のみならず建築工学分野の中で一般に建築衛 生の概念が定着し、学術研究の成果が多く見られ始める。
例えば、大阪市の技師で建築家であった伊藤正文 ${ }^{18-22)}$ は学校建築 等の実建物を対象に実測及び実験を行って研究論文を発表しており、 換気研究が時代に求められて実学として発展した面を実感すること ができる。また、名古屋高等工業學校の佐藤鑑は、水槽を使用した 通風気流解明等の基礎研究 ${ }^{23-24}$ ) 発表し、公衆衛生院（厚生科学研 究所）在籍時には高熱工場をはじめとする換気通風問題に関する研 究を発表している ${ }^{25-26)}$ 。佐藤は東京帝国大學建築科卒の経歴を有し、 建築工学の中で戦前から戦後の計画原論における空気分野の研究を 劧引している。なお、公衆衛生院は関東大震災に関する米国財団か らの復興援助を契機に昭和 13 年に設立されたが、佐藤は昭和 14 年

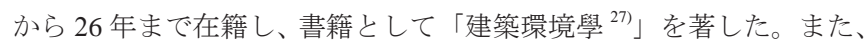
医学系の衛生学者である同院労衝衛生部の石川知福も幅広く室内環 境を取り扱った著書「環境衛生學 ${ }^{28} 」 て ゙$ 空気質と換気量の考え方も 示している。両氏が在籍した頃には建築衛生は衛生学の一分野とし て確立しており ${ }^{291}$ 、同院の当該研究分野の発展への寄与も大きい。

前述の通り、昭和に入って戦前・戦時下の頃から建築工学分野に おいても本格的な換気研究が見られ始めて戦後も継続的に基礎研究 が見られており、換気研究は医学的な衛生学分野から建築分野の研 究者によって多くなされるようになった。例えば東京工業大学にお いては勝田 (千) ${ }^{30)}$ が風力換気の観点から建物群の隣棟間距離と通 風性状の関係を明らかにする風洞実験を実施している。平山・塘 ${ }^{31)}$ は國民衛生に掲載された野村 ${ }^{10)}$ の研究を引用して温度差換気の重要 性に着目し、実験室実験で傾向を詳細に明らかにして理論的考察を 与えている。また、勝田（高）らも東京帝國大の第二工学部におい て密度差による自然換気の実験室実験 ${ }^{32}$ や通風気流性状を明らかに 寸るための風洞実験 ${ }^{33-34)}$ に取り組み、オリフィス式による一般的な 自然換気量算定式の検討も行なっている ${ }^{35)}$ 。この時期には自然換気 について現場実測のみならず比較的緻密な実験室実験が見られるよ うになったが、我が国の工学全体の発展と各研究機関の施設の充実 が背景にあったことも窥い知れる。勝田（高）らは第二工学部が生 産技術研究所に移行した後にも自然換気計算のための流量係数や市 街地における風圧係数整備など基礎資料の充実に向けた検討を行っ ている。その一方で、戦後に増えたコンクリート造集合住宅の換気 実験 ${ }^{36)}$ や学校教室の換気実験も行い、実学に応用するための一般化 を目指した基礎研究を継続的に行なっている。

上記の通り、昭和 10 年代初期から建築工学の中で計画原論の一部 として換気研究が活発に行われ始めたが、昭和 20 年代後半頃からは 計画原論としての体系がまとめられた書籍も多く見られ始める。時 期が早いものとしては伊藤の「建築保健工學 ${ }^{371} 」 か ゙$ 昭和 13 年に出版

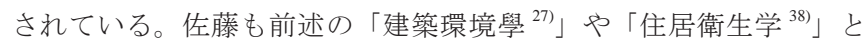
して原論一般の知見をまとめている。木村幸一郎も三木韶とともに 「建築計畫原論 ${ }^{391} 」$ を著しており、「建築学大系 ${ }^{40-411} 」 も$ 組織的にま とめられた。このように、この時期には建築設計のための原論を広 く扱った教科書的な書籍 ${ }^{42-43)}$ が多く見られ始め、学問としての計画 原論の基盤が出来上がった。これらの書籍における換気分野の記述 の典型は、まずL avoisier や Pettenkofer らに言及して換気学説の変遷 を紹介した上で必要換気量の考え方を示し、その上で流体力学に基 ら゙く計算理論を掲載しており、衛生学的な学問の生い立ちを考える とこのような構成を取ることは自然に思われる。また、室内 $\mathrm{CO}_{2}$ 濃 度基準 1,000 ppm について、佐藤 ${ }^{27)}$ はその書籍の中で「污染の総合 
的判断の指標であって真の意味の生理的恕限度ではあり得ないため、 換気計画にあっては常に念頭に置くべき」と述べている。木村 ${ }^{39}$ も $\mathrm{CO}_{2}$ 濃度はあくまで指標であり、「他に空気の新鮮度を表示する適当 なものがないため、今日もなお $\mathrm{CO}_{2}$ が用いられている」と 1949 年出 版の書籍で述べている。その後 70 年近くが経過した現在でも変わる ことなく同基準值が用いられていることになる。しかし、室内 $\mathrm{CO}_{2}$ 濃度基準については、外気濃度の上昇と省エネルギーのための適切 な換気量設定が求められる現代においては再考す心゙き項目であるた め、近年でもまさに国内で議論が交されており ${ }^{44)}$ 、当該分野の研究 の本質は変わっていないことも実感することができる。

\section{4 戦後の換気研究の進展とその成熟}

戦後の昭和 20 年代後半からは、日本建築学会が組織的に計画原論 としてその体系をまとめる活動を行なっており、昭和 27 年に同学会 建築設計々画規準委員会（委員長 渡辺要）が立ち上がった。ここで は研究成果を資料として広く設計者に提供して研究と実務計画の溝 を埋めるべくパンフレットを発刊しており、第３（空気）分科会（主 查 佐藤鑑）からは昭和 32 年に「3. 室内気候設計 $\left.{ }^{45}\right\rfloor$ が出版された。 当該パンフレットは、換気をはじめ空気に関する諸問題における研 究者と設計者の橋渡しを目的としたが、課題が多岐にわたることか ら設計時の各論としての Q\&A をまとめる形式にとどめている。その ため、このパンフレットでは設計に有用な資料が提供されてはいる が、体系的な空気環境の設計法の確立にはまだ至っていない。

発展の歴史を俯瞰すると、この時期は換気研究の歴史の中でも「研 究・設計のためのパーツの整備が始められた時期」のように思われる。 例えば、前述の勝田（高）らのその後の研究では、隙間換気の $p-Q$ 特性整備 ${ }^{46)}$ や換気計画のための市街地建物群の風圧係数資料の整備 47)、さらには換気設備設計の観点からの給排気器具性能の実験によ る検証と理論の提案なども行われている。また、前述の藤井厚二に 教わり、同氏の勧めで戦時中に満州医学校衛生学教室や大陸科学院 建築研究室に在勤した前田敏男は、昭和 25 年に助教授として京都大 学に着任し、以降自然換気や室内気流に関わる研究も行なっている ${ }^{48-49)}$ 。塘 ${ }^{50)}$ は基礎研究として通風量を開口率で説明するための実験な らびに理論提案を行なっている。勝田 (千) ・ 関根ら ${ }^{51-54)}$ も換気筒や 屋根モニター、一般開口及び隙間に関して実験による換気特性の解 明や換気理論の研究を行っている。京都工芸繊維大の石原正雄も同 時期に室内通風気流解明 ${ }^{55)}$ やベンチレーター、越屋根等の自然換気 装置の換気特性 ${ }^{56-58)}$ を解明するための実験を精力的に行なっている。 さらに、この時期には当時水路網や坑道の通気網等に利用されてい た計算法 ${ }^{59-60)}$ を建築に適用した多数室の換気計算の解法に関して、 前田 ${ }^{61)}$ 、石原 ${ }^{62)}$ の報告が見られ、換気計算理論に関してもさらなる ステップアップが見られている。

昭和 35 年には日本建築学会大会において前述の空気分科会で主査 佐藤、幹事勝田 (高) ・ 前田を中心に「換気計算法」を主題とした研 究協議会が開催されている ${ }^{63)}$ 。当該協議会では計算理論と種々の換 気特性を中心に一般的な換気計算法の確立を目指して空気関係の研 究者が発表しており、その議論も踏まえて新たに換気分野の設計パ ンフレットを発刊する計画も記されている。これを受け、その5 年 後となる昭和 40 年には「18 換気設計 ${ }^{64)} 」$ が発刊されており、Q\&A にとどめられた昭和 32 年のパンフレット ${ }^{45)}$ からわずか 8 年で一般的
な換気設計法としてのまとまりを見せた。後年佐藤 ${ }^{65)}$ が評したよう に、換気理論はこの時期めざましく進展したと言え、それまで理論 も技術資料も不十分であったために複雑な問題への対応が難しかっ た状況からの脱却が見られた。同時に、現在の空気環境の教科書的 内容はこの頃にほぼ完成したと思われる。さらに、石原は昭和 44 年

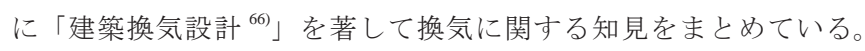
この段階で換気研究は一定の成熟を見せたと筆者は解釈している。

\section{3. 現代の各論としての換気研究の発展 3.1 住宅の換気性能に関する研究}

前述の昭和 40 年代以降は換気量測定法や換気計算の手法に焦点を 当てた研究も行われ、その後は手法の提案や改善を目的に研究が行

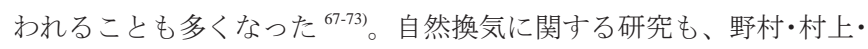
勝田（高）ら ${ }^{73-75)}$ をはじめ継続的に行われている。そのような背景 の中、石油危機が発生して昭和 50 年代には省エネルギーをキーワー ドとした通風研究 ${ }^{76)}$ が見られ始め、当然ではあるが社会問題に対応 する形で時代に求められて研究が行われてきたことがわかる。また、 この時期から建物の気密化が急速に進んだことから、気密性能や換 気設備性能も含めた総合的な換気性能評価の研究も見られるように なった。中でも、住宅については気密性能に関する本格的な調査研

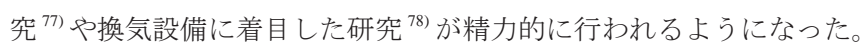
以降の住宅を対象とした換気研究では、自然換気量のみの評価に止 まらず気密性能と換気設備が密接に関わることを深く認識した上で

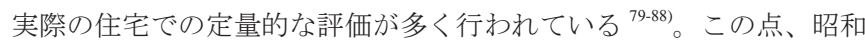
40 年代から進歩して研究の手法や取り扱う範囲が広くなったことで、 より現実的な応用研究が可能になったことがわかる。昭和初期から の通風研究に詳しい吉野 ${ }^{89)}$ のレビューからも、昭和 50 年代中頃以降 は住宅を対象とした自然換気研究が増加して活発に研究が行われて いることがわかる。住宅の自然換気及び通風に関連する研究は近年 でも精力的に行われており、通風性能の評価指標及び資料の検討も 行われている。例えば赤林ら ${ }^{90-91)}$ は通風デグリーアワーの提案を行 なった上で換気回数のグレード毎に有効空面積率マップを作成して おり、住宅の通風を対象とした有用な技術資料を提供している。

\section{2 数值流体力学の導入と発展}

体系を駆使した換気研究が行われ始めた昭和 50 年頃には、様々な 換気通風研究が行われる一方で、東京大学では野村・松尾・貝塚・ 坂本ら ${ }^{92}$ による室内気流を対象とした数值流体力学 (CFD) への本 格的な取り組みが見られた。ここでは Launder·Spalding ${ }^{9394)}$ と同様 に 2 方程式モデルを用いた数值計算が行われ、特に室内三次元乱流 を解析した点が意義深い。乱流のモデリングを含む数值計算である 以上は計算精度が問題となるためその向上の必要性は高く、直後か ら精度検証や計算手法等の各種検討研究 ${ }^{95-96)}$ が見られる。分野の発 展を俯瞰すると、これ以降 CFD が室内気流及び換気問題を考えるた めの現実的かつ新たな研究手法として用いられるようになったと言 える。また、1980年代後半からは基礎研究に限らず実学的な換気研

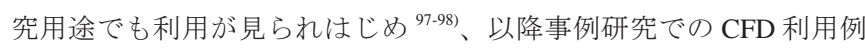
は枚挙に暇がない。CFDではより詳細な性状が得られるため、その 発展は一層高度な検討を可能にし、2000年代以降は商用コードの発 達もあって現代では実務での利用も一般的な時代となっている ${ }^{99)}$ 


\section{3 換気効率指標の提案とその発展}

換気効率指標に関寸る研究に目を向けると、古くは昭和 20 年代 に佐藤 ${ }^{26,29)}$ が通気量に対する污染物排出に有効に働いた換気量の比 率を「換気効率」とした評価も行っているが、昭和 50 年代後半に Sandberg ${ }^{100-102)}$ が A ge (空気齢) の概念が提唱して以降、より定量的 な換気効率評価や室内の詳細な分布にも関心が持たれるようになっ た。また、これが前述の室内三次元乱流解析が行われるようになっ た時期と重なっている。そのような背景の中、村上・加藤による CFD 利用を前提とした新たな換気効率指標としてのSVE1 SVE3 103-104) の提案が見られた。さらに小林・加藤・村上はSVE4 SVE6 105) も提唱し、これが温熱環境形成の指標である CRI ${ }^{106)}$ の提案にも繋 がっている。現代において実務の換気設計や設備設計に用いるCFD での空気齢（SVE3）評価 ${ }^{99}$ 107) が一般に珍しくなくなったことも、こ れらの研究の成果と言える。CFD を用いた換気効率指標としては、 その後も伊藤・加藤・村上 ${ }^{108-109)}$ が Visitation F requency を定義した上 で Local Purging Flow Rateの評価を行っており、近年では Lim・伊藤・ Sandberg ら ${ }^{110-112)}$ により Net Escape Velocity が提案されている。

\section{4 非住宅建築物を対象とした自然換気研究の発展}

前述の通り、昭和 50 年代頃からは住宅を対象に実用的な換気研究 が精力的に行われたが、2000 年代前半頃からはオフィス等の非住宅 建築物を扱う研究例も多くなり、空気齢を評価した例も少なくない 113-114)。この時期からは大規模非住宅建築物でも自然換気の導入が見 られ始め、実建物で評価した研究例 ${ }^{115-122)}$ が多く見られようになった。 その一方で、一般的な知見を得るための取り組みも現在まで多く行 われている ${ }^{123-128)}$ 。高層の非住宅建築物の自然換気設計手法は現在で も体系を成したとは言い難いが、検討すべき課題や手法などの実務

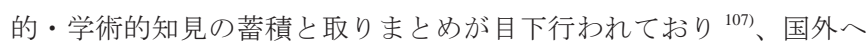

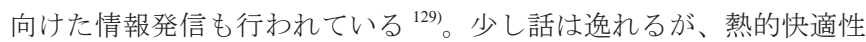
分野では英国 BRS の Charles Webb が終戦直後にシンガポールで実施 した調査に端を発し、その後 Humphreys, Nicol らにより進められて きた A daptive Model ${ }^{130-131)}$ の概念は現在 A SHRAE Standard $55^{132)}$ に組 み込まれている。当該モデルは住宅 / 非住宅を問わず換気設計の立場 から応用の可能性があり、自然換気に関する研究の中で当該モデル を扱う研究の例 ${ }^{133)}$ が今後増えてさらに進展する可能性も期待される。

\section{5 通風量の予測モデルと通風気流の詳細解析}

我が国では、大正期の雑誌國民衛生の時代から通風気流の評価が 行われてきた歴史もあり、通風気流の解明や通風モデルの研究も多 い。通風時の自然換気量はオリフィス式に基づく手法では誤差が大

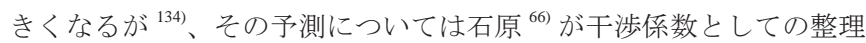
の概念を示し、甲谷・山中 ${ }^{135)}$ は当該係数を流入風向でも整備し、風 向予測を含めた自然換気量予測手法を提案している。加藤ら ${ }^{136-137)}$ は、 オリフィス式に基づく換気量予測はあくまで開口通過前後で速度圧 が無視できる場合に適用可能なため、通風時にはNS 方程式に基づく 流管内エネルギー損失を予測すべきとして、実現象に基づくパワー バランスモデルの概念を示している。当該予測モデルは論理的では あるがエネルギー損失の解明と整備が必要であり、そのため筆者ら 138) もCFDにより流管解析を行い、データ整備を行なっている。また、 倉㴊ら ${ }^{139-140)}$ は通風時に流入風向によって流量係数が変化する問題を
開口部の局所的な力学特性の相似性を表す無次元室内圧によって整 備する局所相似モデルを提案し、概念提示にとどまらずその後も継 続的に必要な知見と資料の整備を行い、一連の研究として継続して

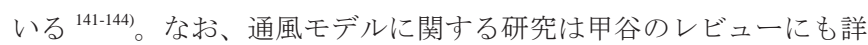
しい ${ }^{145)}$ 。上記とは別問題として、微小な風圧係数差での通風も一般 的な自然換気量予測手法が存在しないため問題となる。その主なメ カニズムは気流の乱れであり、脈動と混合の 2 種 ${ }^{146-148)}$ と言われてい る。乱れによる換気量予測については、単一開口を対象として山中 $ら^{149)}$ や河野・加藤ら ${ }^{150)}$ の研究が見られる。複数開口で風圧係数差 が微小な場合も密集市街地等では起こり得るが、その換気量予測手 法についてはいまだ知見が不足しており、換気計算理論としては久 落した箇所と言え、基礎研究として取り組むべき課題が残っている。

自然換気・通風は居住者が行う行為としては比較的容易かつ単純 であり古来より日本で用いられるものの、流体力学的な現象として は複雑である。そのため、現象の理解のためには高度な研究を必要 とし、通風量予測モデルの研究と並行して風洞実験やCFD を駆使し て詳細を解明するための検討が継続的に行われている ${ }^{151-160) 。 ま た 、 ~}$ 自然換気通風を促進するパッシブな建築的工夫についてもこれまで 研究が行われており、古くは佐藤 ${ }^{24)}$ 、その後石原 ${ }^{56-58)}$ がベンチレーター やモニター、越屋根の風力換気性能を示したが、近年では鳴海ら ${ }^{161)}$ や筆者ら ${ }^{162-164)}$ が越屋根の評価を行なっている。また、他にもソーラー チムニー ${ }^{165-167)}$ や換気塔 ${ }^{168)}$ の換気性能評価の研究が行われており、 自然換気設計時の参考資料となり得る研究が続けられている。

\section{4. まとめ: 換気研究の歴史を振り返り、整理した上での今後の課題}

我が国の自然換気に関する研究は明治期の衛生学を起源として本 格的に始まったという捉え方ができ、その後建築学での取り組みが 見られ始めた。昭和 10 年頃からは建築学の中で計画原論の一部とし て本格的に研究が行われ、戦後には組織的な研究も活発になり、昭 和 40 年代中頃には概社基本体系が出来上がった。その後も測定・計 算技術や評価の方法論が発展したことで、研究は飛躍的に高度化し たと言える。一定の成熟を見せた当該分野で行われてきた研究の位 置づけや意義には、例えば以下のような分類が考えられる。

- 現象の詳細な解明、学術的な欠落箇所の穴埋めなどの基礎研究

・新たな予測モデルや評価指標の提案・精度向上のための基礎研究と それを用いた評価

・新たな実験手法の開発や既存の手法の向上など、研究における評価 の質を向上させるための研究

・各種規準・指針整備のための基礎的検討

・設計一の応用など実学を意図した技術資料の整備と充実

・設計上の新たな工夫と事例研究としての知見の蓄積

・実在システムの定量的評価と課題の抽出

・その時々の社会問題の解決を目指した学術的検討

・隣接する学問分野の知見や技術を導入・応用する研究

このように長い歴史の中で様々な面での研究の発展が見られる中、 本論文で整理を行うことであらためて確認した当該分野の具体的な 課題点を、歴史の中での認識とともに以下にまとめて示す。

• $\mathrm{CO}_{2}$ 濃度 $1000 \mathrm{ppm}$ は Pettenkofer を起源として約 160 年の長きに渡 り慣例的に用いられている。我が国の文献では 130 年以上前より対 象は人体由来と明記され 770 年ほど前も他に適当な指標がないた 
めと指摘されている ${ }^{39)}$ 。近年 pure $\mathrm{CO}_{2}$ の影響に着目する研究が世 界的には見られるものの、日本では継続して同基準を法的に用いて いる。この点は現在再び議論の必要性が広く認識され始めている段 階であり ${ }^{44)}$ 、当該分野に残されている大きな課題の一つと言える。

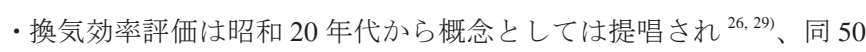
年代の空気齢 ${ }^{100-102)}$ で認識が広まり、数值計算利用を前提とするこ

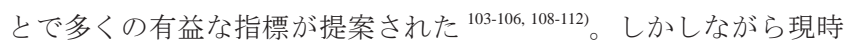
点で実学レベルで広く定着している指標は空気齢まで 99, 107) と言え、 それ以外の換気効率指標の実務レベルでの有効性を示す継続的な検 討の研究は今後大きな可能性を有すると思われる。

・換気設計分野では、高層非住宅建築物の自然換気設計のニーズが高

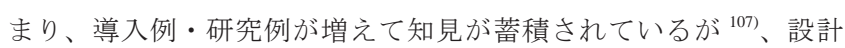
法は確立されておらず分野として久落している。換気設計パンフ レット ${ }^{45,64)}$ がまとめられた際に存在し得なかったニーズであること も理由の一つと考えられ、現代の研究者が体系的にまとめる必要の ある課題と言える。また、自然換気特有の快適性を考慮した自然換 気設計法も今後大いに可能性を秘めていると考えられる。

・多数室換気計算法は昭和 30 年代のめざましい進歩が見られて以降、 オリフィス式と風圧係数に基づいて回路網モデルを解く手法が一般 的となり、実学への応用でも気象データと風圧係数は時間平均值を 入力する手法が常識的である。しかし外部風変動を無視した換気回 路網計算は当時の技術的な「落とし所」であり、LESによる大規模 解析が屋外分野で一般に行われる現在、換気研究においてさらに精 密な計算を目指した研究の実施も当該分野の課題と言える。

・換気力学においては、風圧を用いて通気量を予測する考え方は大正 時代から示されており ${ }^{10)}$ 、現在でもオリフィス式が換気回路網計算 等の基礎式として用いられる。しかし、この式もモデルに過ぎず、

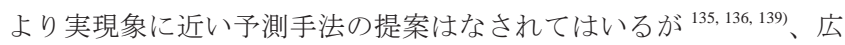
く一般に用いられることのできる換気量の簡易予測式は完成された とは言い難いため、確立に向けた取り組みの学術的意義が大きい。 当該分野では約 50 年前までに完成した換気研究の体系を駆使して 研究を進めることが多い。上記のような課題が残されているのは、 体系の中でも「当時技術的にやむなく採用された落とし所」のよう な手法を踏襲していることも一つの要因とも考えられる。つまり、 本論文であげられなかったものも含めて「囚われる必要のない常識」 や「やむなく用いてきた慣例的手法」は当該分野に多く存在してい ると考えられ、今後それらから脱却して新たな研究の展開へと進む ことができる可能性は大きいと考える。当該分野の研究者がそのよ うな課題をさらに発見するためには、現在用いられている種々の手 法が提案されて常識化した経緯を把握することは重要との考えから、 本研究がその一助となることを願い、これを論文の結びとしたい。

なお、本論文の内容は国内研究発表会 ${ }^{169,170)}$ にて既に発表している。

\section{参考文献}

1) Ito, K. : Breakthrough of Ventilation Research in Architectural Environmental Engineering Field, Proc. of the 25th Al] Air Symposium, pp.1-2, 2016.8 (In Japanese) 2) Subcommittee on technological history of environmental eng. (Chapter 2 by Sekine, T.): Kankyoukougaku gijutushi syouiinkai houkoku (Report of subcommittee on technological history of environmental eng.), J . Archi. Build. Science, Vol.99, No.1227, pp.44-45, 1984.11 (In Japanese)

環境工学技術史小委員会（第 2 章，関根孝）：環境工学技術史小委員会報告， 建築雑誌，Vol. 99, N o.1227, pp.44-45, 1984.11
3) Horikoshi, T., Horikoshi, H. : The theory and design of bioclimatic architecture developed by Koji Fujii, J ournal of Architecture, Planning and Environmental Engineering (Transaction of AlJ ), N 0.386, pp.38-42, 1988.4 (In J apanese) 堀越哲美，堀越英嗣 : 藤井厚二の体感温度を考慮した建築気候設計の理論と住 宅デザイン，日本建築学会計画系論文報告集，第 386 号，pp.38-42, 1988.4

4) Edited by SHASE (Chapter 2.1, Komine, H.) : Kuukichouwa eiseisetsubi gijutsushi (History of HVAC and sanitary technology), pp.13-21, Maruzen, 1991 (In J apanese) 空気調和・衛生工学会編（2.1，小峯裕己）：空気調和・衛生設備技術史， pp.13-21，丸善， 1991.

5) Mori, R. : Rikugun eisei kyoutei (A hygiene course of the army), The army surgeon school, 1889 (In Japanese) 森林太郎: 陸軍衞生呚程，陸軍々醫學校，1889

6) Mori, R. : Zoukaeiseino youshi (A summary of building hygiene), J. Archi. Build. Science, Vol.7, N o.76, pp.115-122, 1893.4 (In Japanese) 森林太郎: 造家衛生の要旨，建築雑誌，第 7 輯，76 號，pp.115-122, 1893.4

7) Tahara, Y. : Tokyofuka shougakkou kuukishikensetsu (A erial experiment in a primary school in Tokyo), Dainihon Shiritsu Eiseikai Zasshi, Vol. 16, pp.1-14, 1884.9 (In J apanese) 田原良純: 東京府下小學校空氣試驗説，大日本私立衛生會雑誌，第 16 號， pp.1-14, 1884.9

8) Tsuboi, J. : Nihonkaoku kankiron (Ventilation in Japanese buildings), Dainihon Shiritsu Eiseikai Zasshi, Vol. 41, pp.61-75, 1886.10 (In Japanese) 坪井次郎 : 日本家屋換氣論，大日本私立衛生會雑誌，第 41 號，pp.61-75, 1886.10

9) Tanaka, H. : Shougakkou kankihou no ippan (An example of Ventilation Strategies of Elementary School), J. Archi. Build. Science, Vol.6, No.66, pp.157-169, 1892.6 (In Japanese)

田中豊輔 : 小學校換氣法の一班，建築雑誌，第 6 輯，第 66 號，pp.157-169, 1892.6

10) N omura, H. : Kaokuno shizenkankini oyobosu kiryuno eikyouni tsuite (Effect of airflow on natural ventilation), The National Hygiene, Vol.1, N 0.5, pp.1-13, 1924.1 (In J apanese) 野村仁: 家屋ノ自然換氣二及ボス氣流ノ影響二就テ 第一篇，國民衛生，第 1 巻，第 5 號，pp.1-13, 1924.1

11) Nomura, $\mathrm{H}$. : Kaokuno shizenkankini oyobosu kakusangensyouno kenkyu (Effect of diffusion on natural ventilation), The National Hygiene, Vol.1, N o.6, pp.21-29, 1924.2 (In J apanese) 野村仁: 家屋ノ自然換氣二及ボス擴散現象之研究 第一篇, 國民衛生, 第 1 巻, 第 6 號，pp.21-29, 1924.2

12) Otani, S. : Nihonkaokuno shizenkankini kansuru sougouteki kenkyu (Natural ventilation in Japanese buildings), The National Hygiene, Vol.5, No.11, pp.1-13, 1928.11 (In J apanese)

大谷佐重郎：日本家屋ノ自然換氣二關スル總合的研究，國民衛生，第 5 巻， 第 11 號，pp.1-13, 1928.11

13) Morita, K. : Kuukichu Tansangasuno Shinteiryouhou (A new technique for $\mathrm{CO}_{2}$ measurement), The National Hygiene, Vol.1, N o.6, pp.1-9, 1924.2 (In J apanese) 森田公平: 空氣中炭酸瓦斯/新定量法, 國民衛生,第 1 巻, 第 6 號, pp.1-9, 1924.2

14) Ooi, Y. : Shitsunaigaino onsani motoduku shizenkankiryouno sokutei (Natural ventilation rate caused by indoor/outdoor temperature difference), The National Hygiene, Vol.3, N 0.9, pp.1-20, 1926.5

大井好成 : 室内外ノ温差二基ク自然換氣量ノ測定，國民衛生，第 3 巻，第 9 號， pp.1-20, 1926.5

15) Fujii, K. : Wagakunino Juutakukenchikuno Kaizenni Kansuru Kenkyu (On the improvement of Residential Buildings in Japan), The National Hygiene, Vol.4, No.4, pp.137-148, 1926.12 (In J apanese)

藤井厚二: 我國住宅建築)改善二關スル研究（承前），國民衛生，第 4 巻，第 4 號, pp.137-148, 1926.12

16) Yanagimachi, S. : D anbou to kanki (Heating and ventilation), Dainihonkougyoukai, 1921 (In J apanese) 柳町政之助 : 煖房之換氣 - 後編, 大日本工業學會，1921

17) Sekito, K. : Kanki to ryoubou (Ventilation and cooling), AlJ Pamphlets, Vol.3, N 0.7, 1930 (In J apanese)

關藤國助 : 換氣と涼房, 建築學會パンフレット,第 3 輯, 第 7 號, 建築學會, 1930

18) Ito, M. : Efficiency of the Ventilating Duct in School-room constructed with Reinforced Concrete, Transactions of the Institute of J apanese Architects, No.3, pp.58-65, 1936.10 (In J apanese)

伊藤正文 : 換氣筒を有する鐵筋コンクリート造教室の自然換氣量に就て，建 築學會論文集，第 3 號，pp.58-65, 1936.10

19) Ito, M. : Model Studies of A eration in the School-room, Transactions of the Institute of J apanese Architects, N 0.3, pp.66-75, 1936.10 (In J apanese) 伊藤正文 : 教室内氣流の模型實驗，建築學會論文集，第 3 號，pp.66-75, 1936.10 20) Ito, M. : The A mount of Dust Variously settled under the School-room A erotion System, 
Transactions of the Institute of J apanese Architects, N 0.9, pp.261-270, 1938.4 (In Japanese)

伊藤正文: 教室内の積塵量と通氣機構に依るその分布變化 : 小學校計畫に於 ける保健的建築施設の研究，建築學會論文集 第 9 號，pp.261-270, 1938.4

21) Ito, M. : Model Studies of Hopper A eration system, Transactions of the Institute of J apanese Architects, N 0.11, pp.24-30, 1938.11 (In Japanese)

伊藤正文 : Hopper 通氣徑路に關する實驗的吟味 : 小學校計畫に於ける保健 的建築施設の研究，建築學會論文集 第 11 號，pp.24-30, 1938.11

22) Ito, M., Kaziwara, S. : A Model Study for the A eration Systems of Industrial Building, Transactions of the Institute of J apanese Architects, N o.17, pp.94-102, 1940.4 (In Japanese)

伊藤正文，梶原三郎：工場の換氣機構に關する模型實驗，建築學會論文集 第 17 號，pp.94-102, 1940.4

23) Sato, A . : On the Air Circuit through Two Openings on the Same Side for Wind Direction, Transactions of the Institute of J apanese Architects, N 0.5, pp.241-251, 1937.3 (In Japanese)

佐藤鑑 : 風向に對し同一側の二開口部による換氣輪道に就て，建築學會論文 集第 5 號，pp.241-250, 1937.3

24) Sato, A . : Comparative Experiments of the Common Monitor with the Screen Monitor, Trans. of the Institute of J apanese Architects, N o.13, pp.360-269, 1939.4 (In J apanese) 佐藤鑑: 在来モニターと遮光併用モニターとの風力による自然換氣の比較 試驗，建築學會論文集 第 13 號，pp.360-369, 1939.4

25) Sato, A . : A Study on the A mount of Air Naturally Exhausted by Industrial Buildings, Transactions of the Institute of J apanese Architects, No.21, pp.85-93, 1941.4 (In Japanese)

佐藤鑑：工場の自然排氣量に就ての考察，建築學會論文集，第 21 號，pp.8593, 1941.4

26) Sato, A. : Ventilation Effects due to Various Types of Air Circuits (Section 2), Transactions of the Architectural Institute of J apan, N o.32-35, pp.31-35, 1947.6 (In Japanese)

佐藤鑑: 通氣徑路による換氣効果の研究 (第 2 部)，日本建築學會論文集，第 $32 \sim 35$ 號, pp.31-35, 1947.6

27) Sato, A . : Kenchikukankyougaku (B uilt Environment), Kigensya, 1948 (In J apanese) 佐藤鑑 : 建築環境學, 紀元社, 1948

28) Ishikawa, T. : K ankyoueiseigaku (Environmental Hygiene), Tohodo, 1942 (In J apanese) 石川知福: 環境衞生學，吐鳳堂，1942

29) Editted by Koya, Y. : K oushuueiseigaku (Public Health), Vol.2, Nippon-Rinsho, 1948 (In J apanese)

古屋芳雄 編: 公衆衛生學, 第 2 輯, 日本臨牀社, 1948

30) Katsuta, C. : Experimental Study on the Natural Ventilation by Wind, Transactions of the Institute of J apanese Architects, N 0.5, pp.261-270, 1937.3 (In J apanese) 勝田千利：通風に關する實驗的研究，建築學會論文集，第 5 號，pp.261-270， 1937.3

31) Hirayama, T. and Tomo, I. : Quantities fo Natural Ventilation due to Temperature Difference Between Inside and Outside of a Room (Report 1), Transactions of the Institute of J apanese Architects, N 0.28, pp.51-57, 1943.2 (In Japanese) 平山嵩，塘一郎 : 室内外温度差に基く自然換氣量 (第 1 報)，建築學會論文集， 第 28 號, pp.51-57, 1943.2

32) Shoda, T. : A n Experimental Study on the Natural Ventilation of a Small Room (1st Report), Transactions of the Institute of J apanese Architects, N 0.28, pp.63-69, 1943.2 (In Japanese)

勝田高司：自然換氣に關する實驗的研究（第 1 報告），建築學會論文集，第 28 號, pp.63-69, 1943.2

33) Watanabe, K., Shoda T. : On the Horizontal Air Current in Typical Southern Houses, Transactions of the Institute of J apanese Architects, N o. 31, pp.145-153, 1944.4 (In Japanese)

渡邊要, 勝田高司: 南方住居の平面型と水平氣流，建築學會論文集，第 31 號， pp.145-153, 1944.4

34) Watanabe, K., Shoda, T. : State of A ir Flow Through Tropical Houses of Different Sections (Section 2), Transactions of the Architectural Institute of J apan, N 0.32-35, pp.43-46, 1947.6 (In J apanese) 渡邊要，勝田高司: 南方住居の斷面型と通風徑路 (第 2 部), 日本建築學會論 文集第 $32 \sim 35$ 號，pp.43-46, 1947.6

35) Shoda, T. : On The Calculation of National Ventilation, Transactions of the Architectural Institute of J apan, N 0.38, pp.100-102, 1949.4 (In Japanese) 勝田高司: 自然換氣量算定式について，日本建築學會論文集 第 38 號。 pp.100-102, 1949.4
36) Shoda, T., Fujii, S. and Konno, K. : Experimental Study on Theoretically Derived Formula for $\mathrm{N}$ atural Ventilation, Transactions of the Architectural Institute of J apan, N 0.47, pp.75-84, 1953.12 (In J apanese)

勝田高司，藤井正一，今野啓一：コンクリート造アパートの換気に関する研 究，日本建築學會論文集 第 47 號，pp.75-84, 1953.12

37) Ito, M. : Kenchiku hoken kougaku (Building Health Engineering), Kougyoutosyo Kabushikigaisya, 1938 (In J apanese)

伊藤正文: 建築保健工學，工業圖書株式會社，1938

38) Sato, A . Juukyo eiseigaku (Residential Hygiene), Sekibundo, 1957 (In Japanese) 佐藤鑑: 住居衛生學，績文堂出版，1957

39) K imura, K. Miki, A : K enchiku keikaku Genron (Science of A rchitectural Planning), K yoritsu Shuppan, 1949 (In J apanese) 木村幸一郎，三木韶：建築計畫原論，共立出版，1949

40) Nimura, T., O giso, S., Kojima, T. et al., : K enchikugaku taikei 8 (A series on architectural Engineering 8), Shokokusha, 1955 (In J apanese) 二村忠元，小木曾定彰，小島武男，ほか 3 名 : 建築学大系 8, 彰国社， 1955

41) Hirayama, T., O giso, S., Watanabe, K., et al. : Kenchikugaku taikei 22 (A series on A rchitectural Engineering 22), Shokokusha, 1957 (In J apanese) 平山嵩，小木曾定彰，渡辺要，ほか 2 名: 建築学大系 22 , 彰国社, 1957

42) Hirayama, T. : K enchikusekkei riron (A rchitectural Design Theory), Kagaku seisaku kyoukai, 1948 (In J apanese) 平山嵩: 建築設計理論，科學政策協會，1948

43) Watanabe, K. : Kenchiku keikaku genron (Science of A rchitectural Planning), Maruzen, 1951 (In Japanese) 渡辺要 : 建築計画原論, 丸善, 1951

44) Yamanaka, T. : History and Future of Indoor $\mathrm{CO}_{2}$ Standard, Proc. of the 24th AlJ Air Symposium, pp.17-20, 2015.9 (In Japanese)

山中俊夫 : 二酸化炭素濃度の基準のあり方, 2015 年日本建築学会 第 24 回 空気シンポジウム, pp.17-20, 2015.9

45) Edited by AIJ A rchitectural Design Planning Standard Committee : AlJ Design Planning Pamphlets, No.3, AlJ, 1957 (In J apanese)

日本建築学会建築設計々画規準委員会 編 : 日本建築学会設計計画パンフ レット3, 日本建築学会，1957

46) Shoda, T., Goto, S., Terasawa T. : The A mout of Ventilation through Craks A round Steel Sashes, Transactions of the Architectural Institute of J apan, N 0.57, pp.205208, 1957.7 (In Japanese)

勝田高司，後藤滋，寺沢達二 : スティール・サッシの寸きまによる換気量，日 本建築学会論文報告集第 57 号, pp.205-208, 1957.7

47) Shoda, T., Goto, S. : Effects of Exposure on Ventilation of Buildings, Transactions of the Architectural Institute of J apan, N 0.53, pp.80-87, 1956.7 (In J apanese) 勝田高司，後藤滋: 建物周囲条件の換気通風に及ぼす影響，日本建築学会論 文報告集 第 53 号，pp.80-87, 1956.7

48) Maeda, T. : Juuryokukankino K enkyu 1- Kanjoutou nituite (on the buoyoancy induced ventilation, A loop of duct), Summaries of Technical Papers of Annual M eeting of AlJ , N 0.15, pp.175-178, 1951.11 (In J apanese)

前田敏男: 重力換気の研究その 1: 環状筒について, 日本建築學會研究報告 第 15 號，pp.175-178, 1951.11

49) Maeda, T. and Maekawa, J. : Shitsunaidanboukiryuni kansuru jikken (Experiment on indoor airflow of heating), Summaries of Technical Papers of Annual M eeting of Al], N 0.17, pp.410-413, 1952.3 (In J apanese)

前田敏男，前川純一: 室内暖房氣流に関寸る實驗，日本建築學會研究報告 第 17 號，pp.410-413, 1952.3

50) Tomo, I. : Kaikouritsuno Kaikoutsuufuuryouni oyobosu eikyouni tuite (Effect of porosity on cross-ventilation rate), Summaries of Technical Papers of Annual M eeting of AlJ , N 0.24, pp.299-300, 1953.10 (In J apanese)

塘一郎: 開口率の開口通風量に及ぼす影響について, 日本建築學會研究報告 第 24 號，pp.299-300, 1953.10

51) Katsuta, C. and Sekine, T. : A n Experimental Study of the Influence of a Highstoried Building upon the Dranght Force in the neighbourhood of the Ventilator or Chimney, Transactions of the Architectural Institute of J apan, N o. 57, pp.193-196, 1957.7 (In Japanese)

勝田千利，関根毅 : 高層建築物の存在が周囲家屋の煙突或は換気筒の通気力に 与える影響について，日本建築学会論文報告集，第 57 号，pp.193-196, 1957.7

52) K atsuta, C., Sekine, T. : The Calculatin Method and the Experimental Study for Ventilator 2, Transactions of the Architectural Institute of J apan, N o. 67, pp.83-89, 1961.2 (In J apanese)

勝田千利，関根毅 : 換気筒計算法と換気筒の実験 (その 2), 日本建築学会論 
文報告集，第 67 号，pp.83-89，1961.2

53) Katsuta, C., Sekine, T. : Experimental Study on Ventilation by the Roof Monitor, Transactions of the Architectural Institute of J apan, No. 68, pp.121-127, 1961.6 (In Japanese)

勝田千利，関根毅 : 屋根モニターによる換気に関する実験的研究，日本建築 学会論文報告集，第68 号，121-127, 1961.6

54) Katsuta, C., Sekine T. : Experimental Study on Ventilation by the Opening of Wall Surface, Transactions of the Architectural Institute of J apan, No. 68, pp.116-120, 1961.6 (In Japanese)

勝田千利，関根毅 : 建築物壁面開口部による換気に関する実験的研究 (その 1)，日本建築学会論文報告集，第 68 号，116-120，1961.6

55) Ishihara, M. : Air Distribution in Rooms by Natural Wind, Transactions of the Architectural Institute of J apan, N o. 54, pp.489-492, 1956.9 (In J apanese) 石原正雄: 通風による室内風速・風向分布について，日本建築学会論文報告 集，第 54 号，pp.489-492, 1956.9

56) Ishihara, M., Awazu S. : Performance Testing of Roof Ventilators, Transactions of the Architectural Institute of J apan, N o. 60, pp.137-140, 1958.10 (In J apanese) 石原正雄，粟津伸一：ルーフ・ベンチレーターの性能，日本建築学会論文報 告集 第 60 号，pp.137-140, 1958.10

57) Ishihara, M. : Ventilation Characteristics of the Monitor Roof, Transactions of the Architectural Institute of J apan, N o. 65, pp.66-72, 1960.6 (In J apanese) 石原正雄: 越屋根の換気性能，日本建築学会論文報告集，第 65 号，pp.66-72， 1960.6

58) Ishihara, M. : Basic Performance of Nature Ventilators, Transactions of the Architectural Institute of J apan, N 0. 69, pp.121-124, 1961.10 (In J apanese) 石原正雄: 自然換気装置の基本的特性，日本建築学会論文報告集 第 69 号， pp.121-124, 1961.10

59) Cross, H. : A nalysis of Flow in N etworks of Conduits or Conductors, University of Illinois Bulletin, N 0.22, Bulletin N 0. 286, 1936.

60) Hiramatsu, Y. : K ounaitsuukino rironto keisan (Underground Mine Ventilation Theory and Calculation), Maruzen, 1953 (In J apanese)

平松良雄 : 坑内通気の理論と計算, 丸善, 1953

61) Maeda, T. : Tasuushitsuno kankikeisanhou (Flow Rate Estimation Method for Multiple rooms), Summaries of Technical Papers of Annual M eeting of AlJ , N 0.57, Kinki branch, pp.57-60, 1961.4 (In Japanese)

前田敏男: 多数室の換気計算法，日本建築学会研究報告，第 57 号，近畿支部， pp.57-60, 1961.4

62) Ishihara, M. : Cross-hou no ouyouniyoru tasuushitsuno kankikeisan (Flow Rate Estimation for Multiple Rooms by Cross Method), Summaries of Technical Papers of Annual M eeting of AlJ , N 0.57, K inki branch, pp.61-64, 1961.4 (In J apanese) 石原正雄 : クロス法の応用による多数室の換気計算，日本建築学会研究報告 第 57 号，近畿支部 pp.61-64, 1961.4

63) Sato, A : Shitsunai kankikeisannitsuite (on the Calculation for Indoor Ventilation), J . Archi. Build. Science, Vol.75, N 0.892, pp.688-689, 1960.12 (In J apanese) 佐藤鑑：室内換気計算について，建築雑誌，第 75 巻，第 892 号，pp.688-689， 1960.12

64) Edited by AIJ A rchitectural Environmental Engineering Committee : AIJ Design Planning Pamphlets, N o.18, Shokokusha, 1965 (In Japanese)

日本建築学会環境工学委員会 編: 日本建築学会設計計画パンフレット 18 , 彰国社, 1965

65) Sato, A : K uukito kenchikukankyou (Air and Built Environment), J . Archi. Build. Science, Vol.96, No.1185, pp.3-5, 1981.10 (In Japanese) 佐藤鑑 : 空気と建築環境，建築雑誌，Vol. 96, No.1185, 1981.10

66) Ishihara, M. : K enchikukankisekkei (Building Ventilation Design), A sakura Shoten, 1969 (In Japanese) 石原正雄 : 建築換気設計，朝倉書店，1969

67) Ishihara, M, Nishioka, T. : Helium gas niyoru kankiryousokuteini kansuru kenkyu (Flow Rate Measurement by Helium Gas), Summaries of Technical Papers of Annual M eeting, Architectural Institute of J apan, Planning, pp.103-104, 1968.10 (In J apanese) 石原正雄，西岡利晃：ヘリウムガスによる換気量測定に関する研究，日本建 築学会大会学術講演梗概集，計画系，pp.103-104, 1968.10

68) Iyoda, A ., Honma, H. : $\mathrm{CO}_{2}$ renzokuhasseiniyoru kankiryousokuteihou nituite (Measurement of ventilation Rate by $\mathrm{CO}_{2}$ constant emission), Summaries of Technical Papers of Annual Meeting, Architectural Institute of J apan, Planning, pp.35-36, 1970.9 (In J apanese)

伊与田温，本間宏：CO 連続発生による換気量測定法について，日本建築学 会大会学術講演梗概集，計画系，pp.35-36, 1970.9
69) Sasaki, T., A ratani, N. : A mesuring method of ventilation-routes and quantities in the multi-room building, Transactions of the Architectural Institute of J apan, No. 333, pp.84-91, 1983.11 (In J apanese)

佐々木隆，荒谷登: 多室空間の換気経路測定法に関する研究，日本建築学会 論文報告集，第 333 号，pp.84-91, 1983.11

70) Hayakawa, S. : Kankikeisan program to sonotekiyourei (Calculation program for ventilation and its application), Summaries of Technical Papers of Annual Meeting, Architectural Institute of J apan, Planning, pp.155-156, 1973.10 (In Japanese) 早川真 : 換気計算プログラムとその適用例，日本建築学会大会学術講演梗概 集，計画系，pp.155-156, 1973.10

71) Okuyama, H. : Theoretical study on the thermal network model in buildings, D octorate thesis in Waseda U niversity, 1987.12 (In J apanese)

奥山博康 : 建築物の熱回路網モデルに関する理論的研究，早稲田大学博士号 学位請求論文, 1987.12

72) Ishida, K., Kamata, M. Chida, Y. et al. : A simplified calculation method of the house infiltration rates with the building air tightness, J ournal of Architecture, Planning and Environmental Engineering (Transaction of AlJ), N 0.438, pp.23-31, 1992.8 (In J apanese)

石田健一，鎌田元康，千田善孝，ほか 2 名: 建物の気密性を用いた換気量の 簡易計算法，日本建築学会計画系論文報告集，第 438 号，pp.23-31, 1992.8

73) Nitta, K., : Study on the variety of theoretical solutions of ventilation network, J ournal of Architecture, Planning and Environmental Engineering (Transaction of AlJ ), N 0.480, pp.31-38, 1996.2 (In Japanese)

新田勝通: 換気回路網における理論解の多様性に関寸る研究, 日本建築学会 計画系論文集，第480 号, pp.31-38, 1996.2

74) Nomura, T., Muramoto, I. et al. : Study on the Ventilation in School Rooms, Summaries of Technical Papers of Annual M eeting, Architectural Institute of J apan, p.531, 1967.10 (In J apanese)

野村豪, 村本至, ほか 2 名: 小中学校教室の通風について - 模型実験による通風 量測定，日本建築学会論文報告集，号外，学術講演要旨集，p.531，1967.10

75) Murakami, S., Shoda, T. et al. : Fuuryokukankinikansuru Kenkyu 1 (on the windinduced ventilation Part 1), Summaries of Technical Papers of Annual M eeting of Al] , Planning, pp.201-208, 1969.11 (In J apanese)

村上周三，勝田高司，ほか 2 名: 風力換気に関する研究その 1 , 日本建築学 会学術研究発表会梗概集，計画系, pp.201-208, 1969.11

76) Chatani, M., Kodama Y., Takada, N. : Kenchikukeikakuniokeru Ecologicalnagijutsu nokenkyu (Ecological technique in architectural engineering), Summaries of Technical Papers of Annual M eeting, Architectural Institute of J apan, Planning, pp.857-858, 1975.10 (In Japanese)

茶谷正洋，小玉祐一郎，高田典夫 : 建築計画におけるエコロジカルな技術の 研究 2, 日本建築学会大会学術講演梗概集，計画系，pp.857-858, 1975.10

77) Murakami, S. Yoshino, H. : Investigation of air-tightness of houses, Transactions of the Architectural Institute of J apan, N 0.325, pp.104-115, 1983.3 (In J apanese) 村上周三，吉野博：住宅の気密性能に関寸る調査研究，日本建築学会論文報 告集，第 325 号，pp.104-115, 1983.3

78) Yoshino, H., Shoda, T., Murakami, S. : Study on ventilating equipment in multifamily housing part 1 , Transactions of the Architectural Institute of J apan, No.306, pp.81-91, 1981.8 (In J apanese) 吉野博，勝田高司，村上周三: 集合住宅における換気設備に関する研究 第 1 報，日本建築学会論文報告集，第 306 号，pp.81-91, 1981.8

79) A kabayashi, S. Murakami, S., Kato, S. et al. : Experimental Study on $\mathrm{N}$ atural Ventilation of Dwellings Part 1, Summaries of Technical Papers of Annual M eeting, Architectural Institute of J apan, Planning, pp.455-456, 1983.9 (In J apanese) 赤林伸一, 村上周三, 加藤信介，ほか 2 名 : 住宅の通風に関寸る実験的研究 : その 1 ・実大の住宅モデルにおける測定，日本建築学会大会学術講演梗概集 , 計画系, 455-456, 1983.9

80) Yoshino, H., Nagatomo, S., Matsumoto, H. et al. : Verification of calculation methods of air infiltration for a detached wooden house : In the case of a single-room model, J ournal of Architecture, Planning and Environmental Engineering (Transaction of AIJ), No.412, pp.19-29, 1990.6 (In J apanese)

吉野博，長友宗重，松本博，ほか 2 名: 木造戸建住宅を対象とした自然換気 量の予測法に関する検証実験 - 間仕切扉を開放して単室とした場合，日本建 築学会計画系論文報告集，第412 号，pp.19-29, 1990.6

81) A kabayashi, S., Murakami, S. et al. : Experimental study on natural ventilation of detached House Part 1, J ournal of Architecture, Planning and Environmental Engineering (Transaction of AIJ ), N 0.456, pp.9-16, 1994.2 (In J apanese) 赤林伸一，村上周三，ほか 2 名: 住宅の換気・通風に関する実験的研究 その 
1，日本建築学会計画系論文集，第456 号，pp.9-16, 1994.2

82) A kabayashi, S., Mizutani, K. et al. : Experimental study on natural ventilation of detached House Part 2, J ournal of Architecture, Planning and Environmental Engineering (Transaction of AlJ ), N 0.464, pp.47-56, 1994.10 (In J apanese) 赤林伸一, 水谷国男, ほか 3 名: 住宅の換気・通風に関寸る実験的研究その 2, 日本建築学会計画系論文集，第 464 号，pp.47-56, 1994.10

83) Sakaguchi, J., A kabayashi, S. : Study on ventilation system of house Part 1, J ournal of Architecture, Planning and Environmental Engineering (Transaction of AlJ), No.488, pp.35-42, 1996.10 (In J apanese)

坂口淳, 赤林伸一: 住宅の換気システムに関寸る研究その 1, 日本建築学会 計画系論文集，第 488 号，pp.35-42, 1996.10

84) A kabayashi, S., Sakaguchi, J. : Study on ventilation system of house Part 2, J ournal of Architecture, Planning and Environmental Engineering (Transaction of AlJ), N o.512, pp.33-37, 1998.10 (In J apanese)

赤林伸一，坂口淳: 住宅の換気システムに関する研究その 2 , 日本建築学会 計画系論文集，第 512 号，pp.33-37, 1998.10

85) Yoshino, H., K obayashi, $H$. et al. : Evaluation of ventilation system performance by age of air using a test house, J ournal of Architecture, Planning and Environmental Engineering (Transaction of AlJ ), N 0.502, pp.37-42, 1997.12 (In J apanese) 吉野博，小林仁，ほか 2 名: 試験家屋を用いた換気システムの空気齢による 性能評価，日本建築学会計画系論文集，第 502 号，pp.37-42, 1997.12

86) K urabuchi, T., A rashiguchi, A., Imano, M. et al. : Evaluation of Fulfilled Level of Ventilation Rate R equirement on Constantly Ventilated A partment Houses B ased on Frequency of Wind Pressure Acting on External Wall of Building Part 1, Trans. of SHASE, N o.83, pp.53-63, 2001.10 (In J apanese)

倉渕隆，嵐口晃宏，今野雅，ほか 3 名: 風圧力発生頻度に基づく常時換気シ ステムの設備された集合住宅の換気量充足度評価に関する研究 第 1 報，空気 調和・衛生工学会論文集，N o.83, pp.53-63, 2001.10

87) Yoshino, H., Liu, J. et al. : Study on the performance evaluation of hybrid ventilation system for a detached house Part 1, Journal of Environomental Engineering (Transactions of AIJ), N 0.566, pp.57-64, 2003.4 (In J apanese) 吉野博，劉京，ほか 2 名: 住宅用ハイブリッド換気システムの性能評価に関 寸る研究その 1, 日本建築学会環境系論文集，第 566 号，pp.57-64, 2003.4

88) K urabuchi, T., Toriumi, Y. et al. : Study on the Performance Evaluation of Various Ventilation Systems in Consideration of Outdoor Environment of Building and Building A ir-tightness Part 1, Trans. of SH ASE, N 0.117, pp.1-10, 2006.12 (In J apanese) 倉㴊隆，鳥海吉弘，ほか 4 名：地域性・建物気密性能を考慮した各種換気 システムの性能評価に関する研究 第 1 報, 空気調和・衛生工学会論文集， No.117, pp.1-10, 2006.12

89) Yoshino, H. : Syushisetsumei (Purpose of the Symposium), Proc. of the 1st AlJ Air Symposium, pp.1-2, 1990.11 (In J apanese)

吉野博: 第 1 回 空気シンポジウム趣旨説明，日本建築学会第 1 回空気シン ポジウム, pp.1-2, 1990.11

90) A kabayashi, S., Sakaguchi, J., et al. : Evaluation of cross ventilation performance of the detached house with cross ventilation degree hours of inside area, J ournal of Environomental Engineering (Transactions of AlJ), Vol.73, N 0.633, pp.1261-1266, 2008.11 (In Japanese)

赤林伸一，坂口淳，他 3 名: 室内気流分布を考慮した通風性能評価に関する 研究 - 室内通風デグリーアワーを用いた戸建住宅の通風性能評価，日本建築 学会環境系論文集，第 73 巻，第633 号,pp.1261-1266, 2008.11

91) A rinami, Y., A kabayashi, S., Oshima, T., Sakaguchi, J. : Study on the evaluation of cross ventilation performance of detached house by effective air change rate and effective opening area of windows ratio, Journal of Environomental Engineering (Transactions of AIJ ), Vol.78, N 0.685, pp.277-284, 2013.3 (In J apanese) 有波裕貴，赤林伸一，大嶋拓也，坂口淳: 有効換気回数及び有効空面積率に よる住宅の通風性能評価に関する研究，日本建築学会環境系論文集，第 78 巻，第 685 号，pp.277-284, 2013.3

92) N omura, T., Matsuo, Y., K aizuka, M., Sakamoto, Y., Endo, K. : Numerical study of room air distribution 3, Transactions of the Architectural Institute of J apan, N 0.238 , pp.59-67, 1975.12 (In J apanese)

野村豪，松尾陽，貝塚正光，坂本雄三，遠藤清尊: 室内空気分布の数值解法 に関する研究・3, 日本建築学会論文報告集，第 238 号, pp.59-67, 1975.12

93) Launder, B. E. and Spalding, D. B. : Mathematical Models of Turbulence, A cademic Press, 1972

94) Launder, B. E. and Spalding, D. B.: The numerical computation of turbulent flows, Comput. M ethods Appl. M ech. Eng., Vol. 3, pp.269-289, 1974

95) Nomura, T., Matsuo, Y. et al. : Numerical solution and wind tunnel experiment of turbulent flow : on air distribution and gas diffusion around a building, Transactions of the Architectural Institute of J apan, N 0.252, pp.57-63, 1977.2 (In J apanese) 野村豪，松尾陽，ほか 5 名: 乱流の数值解析と風洞実験 - 建物周辺の気流分 布と污染物拡散，日本建築学会論文報告集，第252 号，pp.57-63, 1977.2

96) Nomura, T. Matsuo, Y., Kato, S. : Study on Prediction Method of Room A ir Distribution U sing Numerical A nalysis 1, Transactions of the Architectural Institute of J apan, N 0.292, pp.61-72, 1980.6 (In J apanese)

野村豪，松尾陽，加藤信介：数值解析手法を用いる室内空気分布予測法に関 する研究その 1, 日本建築学会論文報告集，第 292 号，pp.61-72, 1980.6

97) Murakami, S., Kato, S., et al. : Study on A ir Velocity Distribution in Conventional Flow Type Clean Room Part 1, Trans. of SHASE, N 0.37, pp.37-48, 1988.6 (In J apanese) 村上周三，加藤信介，ほか 1 名 : コンベンショナルフロー型クリーンルーム 内の気流性状に関寸る研究 第 1 報，空気調和・衛生工学会論文集，N 0.37 , pp.37-48, 1988.6

98) Murakami, S., Yoshino, H., et al. : Ventilating Performance of Vertical Exhaust Duct in a Multi-story House : Model Experiment and Computer Simulation for Pressure Distribution through the Exhaust Duct, Trans. of SHASE, N 0.42, pp.37-47, 1990.2 (In J apanese) 村上周三，吉野博，ほか 3 名: 集合住宅の共用排気ダクト設計方法に関する 研究 - 合流損失に関寸る模型実験およびダクト内圧力分布に科する数值解 析，空気調和・衛生工学会論文集，N 0.42, pp.37-47, 1990.2

99) Edited by SHASE, Guidebook of Computational Fluid Dynamics, O hmsha, 2017 (In J apanese)

空気調和・衛生工学会編：はじめての環境・設備設計シミュレーション CFD ガイドブック，オーム社，2017

100) Sandberg, M. : What is ventilation efficiency?, Building and Environment, Vol. 16, Issue.2, pp.123-135, 1981

101) Sandberg, M. and Sjöberg, M. : The use of moments for assessing air quality in ventilated rooms, Building and Environment, Vol. 18, Issue 4, pp.181-197, 1983

102) Etheridge, D. and Sandberg, M. : B uilding Ventilation - Theory and Measurement, Wiley, 1996

103) Murakami, S., K ato, S. : New Scales for Ventilation Efficiency and Calculation Method by Means of 3-Dimensional Numerical Simulation for Turbulent Flow : Study on Evaluation of Ventilation Efficiency in Room, Trans. of SHASE, N 0.32, pp.91-102, 1986.10 (In Japanese)

村上周三，加藤信介：新たな換気効率指標と三次元乱流数值シミュレー ションによる算出法 - 換気効率の評価モデルに関する研究，空気調和・衛 生工学会論文集, N 0.32, pp.91-102, 1986.10

104) K ato S., Murakami S. : New ventilation efficiency scales based on simulations, ASHRAE Transactions, Vol. 94, N o. 2, pp. 309-330, 1988

105) Kobayashi, H., Kato, S., Murakami, S. : Scales for Evaluating Ventilation Efficiency as Affected by Supply and Exhaust Openings B ased on Spatial Distribution of Contaminant by Means of Numerical Simulation, Trans. of SHASE, No.68, pp.29-36, 1998.1 (In J apanese) 小林光，加藤信介，村上周三：不完全混合室内における換気効率・温熱環 境形成効率評価指標に関する研究 第 1 報, 空気調和・衛生工学会論文集， No.68, pp.29-36, 1998.1

106) K ato, S., K obayashi, H., Murakami, S. : Scales for A ssessing Contribution of Heat Sources and Sinks to Temperature Distributions in Room by Means of Numerical Simulation, Trans. of SHASE, N 0.69, pp.39-47, 1998.4 (In Japanese) 加藤信介，小林光，村上周三 : 不完全混合室内における換気効率・温熱環 境形成効率評価指標に関寸る研究 第 2 報, 空気調和・衛生工学会論文集, N 0.69, pp.39-47, 1998.4

107) Edited by AIJ, Natural Ventilation Design Handbook, Gihodoshuppan, 2013 (In Japanese)

日本建築学会編: 実務者のための自然換気設計ハンドブック，技報堂出版，2013

108) Ito, K., K ato, S., Murakami, S. : Study of visitation frequency and purging flow rate based on averaged contaminant distribution : Study on evaluation of ventilation effectiveness of occupied space in room, J ournal of Architecture, Planning and Environmental Engineering (Transaction of AlJ ), No.529, pp.31-37, 2000.3 (In Japanese)

109) K ato, S., Ito, K., Murakami, S. : A nalysis of visitation frequency through particle tracing method based on LES and model experiment, Indoor Air, Vol.13, pp.182193,2003

110) Lim, E., Ito, K., Sandberg, M. : N ew Ventilation Index for evaluating imperfect mixing condition- A nalysis of Net Escape Velocity based on RANS A pproach , Building and Environment, Vol.61, pp. 45-56, 2013

111) Lim, E., Ito, K., Sandberg, M. : Performance evaluation of contaminant removal 
and air quality control for local ventilation systems using the ventilation index $\mathrm{Net}$ Escape Velocity, Building and Environment, Vol.79, pp78-89, 2014

112) Chung, J., Lim, E., Sandberg, M., Ito, K. : Returning and net escape probabilities of contaminant at a local point in indoor environment, Building and Environment, Vol.125, pp.67-76, 2017

113) Kuwahara, R., A kabayashi, S. et al. : A ir conditioning systems and ventilation efficiency in buildings Part 1, J ournal of Architecture, Planning and Environmental Engineering (Transaction of AIJ), N o.517, pp.29-36, 1999.3 (In Japanese) 桑原亮一, 赤林伸一，ほか 2 名 : 建物の空調・換気効率に関寸る研究その 1 , 日本建築学会計画系論文集，第 517 号, pp.29-36, 1999.3

114) A kabayashi, S., Sakaguchi, J. et al. : Study on air exchange effectiveness in office Part 1, J ournal of Architecture, Planning and Environmental Engineering (Transaction of AlJ ), N 0.516, pp.39-46, 1999.2 (In J apanese)

赤林伸一，坂口淳，ほか 5 名: オフィスビルを対象とした換気効率に関す る研究その 1 , 日本建築学会計画系論文集, 第 516 号, pp.39-46, 1999.2

115) Chikamoto, T., Murakami, S., Kato, S. et al. : Study on Hybrid A ir Conditioning System using $N$ atural Ventilation in Office Space (Part 1), Summaries of Technical Papers of Annual Meeting, Architectural Institute of J apan, D2, pp.597-598, 1997.9 (In Japanese)

近本智行，村上周三，加藤信介，ほか 3 名 : 冷房時のオフィス空間における 自然換気併用ハイブリッド空調方式に関する研究：( その 1)，日本建築学 会大会学術講演梗概集，D2, pp.597-598, 1997.9

116) Togari, S. : Energy conservation effect of passive convective cooling in office buildings, Summaries of Technical Papers of Annual Meeting, Architectural Institute of J apan, D2, pp.583-584, 1999.9 (In J apanese)

戸河里敏: オフィスビルを対象とした自然換気利用について，日本建築学 会大会学術講演梗概集，D2, pp.583-584, 1999.9

117) Cho, S. W., Kimura, K. : Study on the performance prediction of solar chimney in natural ventilation system for a school building, J ournal of Architecture, Planning and Environmental Engineering (Transaction of AlJ), N o.537, pp.37-42, 2000.11 (In J apanese)

趙戬佑，木村建一: 校舎建築の自然換気システムにおけるソーラーチム 二ーの性能予測に関する研究，日本建築学会計画系論文集，第 537 号， pp.37-42, 2000.11

118) Hosoi, A., Narita, S., Sunaga, N. : Measurement survey on natural ventilation Part 1, J ournal of Architecture, Planning and Environmental Engineering (Transaction of AlJ ), No.564, pp.25-31, 2003.2 (In Japanese)

細井昭憲, 成田樹昭, 須永修通: 自然通風に関する実測研究その 1 , 日本建 築学会計画系論文集，第 564 号，pp.25-31，2003.2

119) Mizuide, K., Ishino, H., K ohri, K. et al. : A study on performance evaluation and control method design about a hybrid airconditioning system with a combination of natural ventilation and ceiling fans, J ournal of Environomental Engineering (Transactions of AIJ ), N 0.604, pp.69-76, 2006.6 (In J apanese)

水出喜太郎，石野久彌，郡公子，ほか 4 名: 自然換気・シーリングファンを 併用した空調換気システムの制御手法と性能評価に関する研究, 日本建築 学会環境系論文集，第604 号, pp.69-76, 2006.6

120) Lim, E., Sagara, K., Yamanaka, T. et al. : Mechanism of Structure of Indoor A irflow and Thermal Environment in Office Room with Task-A mbient Air-Conditioning and Natural Ventilation, Trans. of SHASE, No.141, pp.19-28, 2008.12 (In J apanese)

121) Yasunaga, R., A shiya, T., Shiraishi, Y. et al. : Hybrid air-conditioning system using natural ventilation in an office building with flow control inlets and outlets (Part 1), J ournal of Environomental Engineering (Transactions of AIJ), Vol.77, No.678, pp.681-688, 2012.8 (In J apanese)

安永龍一，芦谷友美，白石靖幸，ほか 2 名: 流量制御機能を有する給排気 口を設置したオフィスビルにおける自然換気及び空調システムの併用手法 に関寸る研究（第一報），日本建築学会環境系論文集，第 77 巻，第 678 号， pp.681-688, 2012.8

122) Sakaguchi, T., Yamanaka, T., K otani, H. et al. : Thermal environment in a school building with natural ventilation chimney using staircase in winter, J ournal of Environomental Engineering (Transactions of AlJ), Vol.79, No.703, pp.763-770, 2014.9 (In J apanese)

123) Yamamoto, Y., Kuboki, M. et al. : Investigation on management of natural ventilation system, J ournal of Environomental Engineering (Transactions of AlJ), No.619, pp.9-16, 2007.9 (In J apanese)

山本佳嗣，久保木真俊，ほか 2 名: 自然換気システムの運用実態に関する 調查，日本建築学会環境系論文集，第619 号，pp.9-16, 2007.9

124) Kim, J., Kawaguchi, T., Tanabe, S. : The behavioral characteristic of office workers use of natural ventilation window, J ournal of Environomental Engineering (Transactions of AlJ), Vol.74, N 0.643, pp.1075-1082, 2009.9 (In Japanese)

金政秀，川口知真，田辺新一: 執務者による自然換気空の開閉行為に関する 研究, 日本建築学会環境系論文集，第 74 巻，第 643 号，pp.1075-1082, 2009.9

125) Lim, E., Yamanaka, T. et al. : Temperature and contaminant concentration distribution and energy saving inside an office room with hybrid air-conditioningsystem with windforced ventilation, J ournal of Environomental Engineering (Transactions of AlJ), Vol.75, No.648, pp.171-178, 2010.2 (In Japanese)

126) Miura, K., Takemasa, Y., Yoshida, H. : Evaluation of thermal load reduction and effect to indoor environment by hybrid ventilation system, J ournal of Environomental Engineering (Transactions of AIJ ), Vol.76, N No.660, pp.159-168, 2011.2 (In J apanese) 三浦克弘，武政祐一，吉田治典: 自然換気併用空調システムがもたらす空 調負荷削減効果と室内環境に与える影響の評価，日本建築学会環境系論文 集，第 76 巻、第 660 号, pp.159-168, 2011.2

127) Shoji, K., Kuwahara, M. et al. : Indoor air quality and energy conservation effect of natural ventilation on office building, J ournal of Environomental Engineering (Transactions of AlJ), Vol.77, N 0.679, pp.729-735, 2012.9 (In J apanese) 庄司研，桑原三香，ほか 5 名 : 事務所ビルにおける自然換気時の室内空気 質環境および省エネルギー性に関する研究，日本建築学会環境系論文集， 第 77 巻,第 679 号, pp.729-735, 2012.9

128) Yamamoto, Y., Tanabe, S. : The criteria of outdoor conditions for operating natural ventilation openings, J ournal of Environomental Engineering (Transactions of AlJ ), Vol.81, No.722, pp.375-384, 2016.4 (In Japanese) 山本佳嗣，田辺新一：自然換気システムの換気口開放条件に関する研究， 日本建築学会環境系論文集 第 81 巻，第 722 号，pp.375-384，2016.4

129) Edited by AIJ, Translated by K otani, H. : Natural Ventilation Design Handbook for A rchitects and Building Engineers, Gihodoshuppan, 2016 (E-book)

130) Nicol, F., Humphreys, M., Roaf, S. : A daptive Thermal Comfort - Principles and Practice, Routledge, 2012

131) Humphreys, M., Nicol, F., Roaf, S. : A daptive Thermal Comfort - Foundations and A nalysis, Routledge, 2016

132) ANSI/A SHRAE Standard 55-2013: Thermal Environmental Conditions for Human Occupancy, A SHRAE, 2013

133) Toe, D.H.C., Kubota, T. : Development of an adaptive thermal comfort equation for naturally ventilated buildings in hot-humid climates using ASHRAE RP-884 database, F rontiers of Architectural Research, Vol.2, pp.278-291, 2013

134) K obayashi, T., Sagara, K., Yamanaka, T. et al. : Stream Tube based A nalysis of Problems in Prediction of Cross-Ventilation Rate, Int. J. Vent., Vol.7, N o.4, pp.321-334, 2009

135) Kotani, H., Yamanaka, T. : Prediction of inflow direction at large Ipening of cross ventilated apartment building, J ournal of Environomental Engineering (Transactions of AlJ) ), No.609, pp.39-45, 2006.11

136) Kato, S. : Flow Network Model based on Power Balance as A pplied to CrossVentilation, Int. J. Vent., Vol.2, N 0.4, pp.395-408, 2004.3

137) Murakami, S., Kato, S, A kabayashi, S. et al. : Wind Tunnel Test on VelocityPressure Field of Cross-Ventilation with Open Windows, ASH RAE Trans., Vol.97, Part1, pp.525-538, 1991

138) Kobayashi, T., Sagara, K., Yamanaka, T. et al.: Power transportation inside stream tube of cross-ventilated simple shaped model and pitched roof house, Building and Environment, Vol. 44, Issue 7, pp.1440-1451, 2009.7

139) Kurabuchi, T., Ohba, M., Endo, T. et al. : Local Dynamic Similarity Model of CrossVentilation Part1 - Theoretical Framework, Int. J. Vent., Vol.2 N 0.4, pp.371-382, 2004.3

140) Kurabuchi, T., Ohba, M., Endo, T., A kamine, Y. : Prediction accuracy of flow rate of cross-ventilated buildings (Part 1), J ournal of Environomental Engineering (Transactions of AlJ ), N o.607, pp.37-41, 2006.9 (In J apanese) 倉㴊隆，大場正昭，遠藤智行，赤嶺嘉彦：通風時の換気量予測法に関する研 究（第 1 報），日本建築学会環境系論文集，第607 号，pp.37-41，2006.9

141) Ohba, M., Kurabuchi, T., Goto, T. et al. : Prediction accuracy of flow rate of crossventilated buildings (Part 2), J ournal of Environomental Engineering (Transactions of AlJ ), N o.617, pp.25-30, 2007.7 (In J apanese) 大場正昭，倉㴊隆，後藤伴延，ほか 3 名：通風時の換気量予測法に関する研 究（第 2 報），日本建築学会環境系論文集，第 617 号，pp.25-30, 2007.7

142) Nonaka, T., Kurabuchi, T., Ohba, M. et al. : Study on proper design method of locating windows aiming at utilization of cross-ventilation in densely populated residential area (Part 1), J ournal of Environomental Engineering (Transactions of AIJ), Vol.74, N o.642, pp.951-956, 2009.8 (In J apanese) 
野中俊宏, 倉㴊隆, 大場正昭，ほか 3 名: 密集市街地における効果的な通風 利用を目的とした開口部配置計画手法に関する研究（第 1 報），日本建築 学会環境系論文集，第 74 巻，第 642 号，pp.951-956, 2009.8

143) Endo, T., K urabuchi, T., A kamine, Y. : Development of the test procedure and the database of cross-ventilation characteristic of various opening, J ournal of Environomental Engineering (Transactions of AlJ ), Vol.74, N o.646, pp.1315-1320, 2009.12 (In Japanese)

遠藤智行，倉渕隆，赤嶺嘉彦，ほか 2 名 : 流入開口部通気特性評価法の開発 及び通気特性データベースの構築，日本建築学会環境系論文集，第 74 巻， 第 646 号，pp.1315-1320, 2009.12

144) Goto, T., Ohba, M., K urabuchi, T. et al. : Prediction accuracy of flow rate of crossventilated buildings (Part 2), J ournal of Environomental Engineering (Transactions of AlJ ), Vol.77, N 0.674, pp.259-266, 2012.4 (In J apanese)

後藤伴延，大場正昭，倉㴊隆，ほか 4 名 : 流出開口部への局所相似モデルの 適用に関寸る検討 - 通風時の換気量予測法に関寸る研究（第 3 報），日本建 築学会環境系論文集，第 77 巻，第 674 号，pp.259-266, 2012.4

145) Kotani, H. : A Review of Cross Ventilation Mpdelling Research, Wind Engineers, J AWE, Vol.30, N 0.4 (N o.105), 2005.10 (In Japanese)

146) Haghighat, F., Rao, J., Fazio, P. : The Influence of Turbulent Wind on A ir Change Rates - A Modeling A pproach, Building and Environment, Vol.26, No2, pp.95109, 1991

147) Haghighat, F., B rohus, H., Rao, J. : Modelling air infiltration due to wind fluctuations - a review, Building and Environment, Vol.35, pp.377-385, 2000

148) Narasaki, M., Yamanaka, T., Higuchi, M. : Design Method of Wind-forced Ventilation including Effect of Turbulence of Wind on Ventilation Part 1, Trans. of SHASE, N 0.39, pp.25-34, 1989.2, (In J apanese)

楢崎正也，山中俊夫，樋口祥明: 風の乱れを考慮した換気設計法に関する 研究第 1 報，空気調和・衛生工学会論文集，No.39, pp.25-34, 1989.2

149) Yamanaka, T., K otani, H., Iwamoto, K., K ato, M. : N atural, Wind-Forced Ventilation caused by Turbulence in a Room with a Single O pening, Int. J . Vent., Vol.5, N o.1, pp.179-187, 2006

150) K ono, R., K ato, S., Ooka, R., Takahashi, T. : The study on characteristics of ventilation with single-sided opening Part 3, Journal of Environomental Engineering (Transactions of AlJ), Vol.73, N 0.626, pp.437-443, 2008.4 (In Japanese)

151) K otani, H., Satoh, R., Yamanaka, T. : Natural ventilation of light well in high-rise apartment building, Energy and Buildings, Vol.35, Issue 4, pp.427-434, 2003

152) Iino, Y., K urabuchi, T. et al. ; Study on air flow characteristics of cross-ventilation in and around building for various conditions of openings and different angle of approaching wind using wind tunnel experiment and CFD simulation, J ournal of Architecture, Planning and Environmental Engineering (Transaction of AlJ ), N o.52-, pp.47-54, 1999.6 (In J apanese)

飯野由香利，倉渆隆，ほか 2 名：風洞実験およびCFD を併用した通風時の 開口条件や主風向が異なる場合における建物内外の気流性状に関する研 究，日本建築学会計画系論文集，第 520 号，pp.47-54, 1999.6

153) Kurabuchi, T., Ohba, M. et al. : A nalysis of airflow of cross-ventilated buildings based on LES and wind tunnel experiment (Part 1), J ournal of Architecture, Planning and Environmental Engineering (Transaction of AlJ ), No.561, pp.47-52, 2002.11 (In J apanese)

倉㴊隆，大場正昭，ほか 2 名: LES と風洞実験による建物通風気流構造 の解明に関する研究（第 1 報），日本建築学会計画系論文集，第 561 号， pp.47-52, 2002.11

154) Kurabuchi, T., Ohba, M. Endo, T. : A nalysis of airflow of cross-ventilated buildings based on LES and wind tunnel experiment (Part 2), Journal of Environomental Engineering (Transactions of AlJ), N 0.591, pp.7-13, 2005.5 (In Japanese)

倉㴊隆，大場正昭，遠藤智行：LES と風洞実験による建物通風気流構造の 解明に関寸る研究（第 2 報），日本建築学会環境系論文集，第 591 号，pp.7$13,2005.5$

155) Hiyama, K., K ato, S., Takahashi, T., K ono, R. : Study on effect of openng area ratio and relative opening location on air flow characteristics in cross-ventilation models, J ournal of Environomental Engineering (Transactions of AIJ), N 0.596 , pp.21-27, 2005.10 (In J apanese)

樋山恭助，加藤信介，高橋岳生，河野良坪 : 開口面積比及び開口位置関係が 通風時気流性状に与える影響の分析，日本建築学会環境系論文集，第 596 号, pp.21-27, 2005.10

156) Kobayashi, T., Sagara, K., Yamanaka, T. et al. : Wind D riven Flow through
Openings - A nalysis of the Stream Tube, Int. J . Vent., Vol. 4, Number 4, pp.323$336,2006.3$

157) K obayashi, T., Sagara, K., Yamanaka, T., K otani, H. et al. : Experimental investigation and accuracy study of CFD analysis for flow field around crossventilated building, J ournal of Environomental Engineering (Transactions of AIJ), Vol.74, N o.638, pp.481-488, 2009.4 (In J apanese)

158) Takano, Y., A kabayashi, S., Tominaga, Y. et al. : Study on naturally crossventilated house using large-eddy simulation (LES) part 1, Journal of Environomental Engineering (Transactions of AlJ), Vol.80, N o.716, pp.925-934, 2015.10 (In Japanese)

高野康夫，赤林伸一，富永禎秀，ほか 3 名: LES (Large-Eddy Simulation) に 上る住宅の自然換気・通風性状に関寸る研究 その 1 , 日本建築学会環境系 論文集，第 80 巻，第 716 号，pp.925-934, 2015.10

159) K otani, H., Kobayashi, T. : A ccuracy verification of processing methodology in particle image velocimetry for flow around building, J ournal of Environomental Engineering (Transactions of AlJ), Vol.80, N o.715, pp.741-749, 2015.9

160) A rinami, Y., A kabayashi, S., Tominaga, Y. et al. : Study on naturally crossventilated house using large-eddy simulation (LES) part 2, Journal of Environomental Engineering (Transactions of AlJ), Vol.81, No.725, pp.589-597, 2016.7 (In Japanese)

有波裕貴，赤林伸一，富永禎秀，ほか 3 名 : LES (Large-Eddy Simulation) に よる住宅の自然換気・通風性状に関寸る研究その 2 , 日本建築学会環境系 論文集，第 81 巻，第 725 号，pp.589-597, 2016.7

161) Narumi, D., Habara, H. et al. : Effect of the monitor roof on the indoor thermal environment and property ofnatural ventilation in the room, AlJ J ournal of Technology and D esign, Vol.13, N o.26, pp.617-622, 2007.12 (In J apanese) 鳴海大典, 羽原宏美, ほか 3 名 : 越屋根による建物の室内熱環境制御効果に関 する研究，日本建築学会技術報告集，第 13 巻，第 26 号，pp.617-622, 2007.12

162) Kobayashi, T., Yamanaka, T., K otani, H. et al. : Ventilation performance of montior roof provided for a pitched-roof detached house, J ournal of Environomental Engineering (Transactions of AlJ ), Vol.75, N 0.653, pp.595-601, 2010.7 (In Japanese)

163) Kobayashi T., Chikamoto T., Osada K. : Evaluation of Ventilation Performance of Monitor Roof in Residential A rea based on Simplified Estimation and CFD A nalysis, Building and Environment, Vol. 63, pp.20-30, 2013.5

164) K obayashi, T., Chikamoto, T., U memiya, N., Osada, K. : Estimation of natural ventilation flow rate for a pitched-roof detached house provided with montior roof, J ournal of Environomental Engineering (Transactions of AlJ), Vol.81, No.719, pp.83-91, 2016.1 (In J apanese)

165) A dam, Z., Yamanaka, T., K otani, H. : Simulation study on solar assisted ventilation systems, - Unsteady-state simulation of a detached building with solar chimney using weather data, J ournal of Environomental Engineering (Transactions of AlJ), N 0.577, pp.19-26, 2004.3

166) Nabeshima, Y., Song, S. : Study on the Best Form of Solar Chimney by Model Experiment and CFD Simulation, Trans. of SHASE, N 0.156, pp.11-18, 2010.3 (In J apanese) 鍋島佑基，宋城基 : 模型実験と CFD シミュレーションによるソーラーチ ムニーの最適な形状に関する検討，空気調和・衛生工学会論文集，N o.156, pp.11-18, 2010.3

167) Song, S. : Study on the natural ventilation performance by the connection conditions of the solar chimney and chimney shaft using the model experiment, J ournal of Environomental Engineering (Transactions of AlJ ), Vol.79, No.697, pp.255-260, 2014.3 (In Japanese)

宋城基 : 模型実験によるソーラーチムニーとチムニーシャフトの接続状態 による自然換気性能の検討，日本建築学会環境系論文集，第 79 巻，第 697 号, pp.255-260, 2014.3

168) Takizawa, M., Kurabuchi, T., Narumi, D. et al. : Study on draft and ventilation promotion using a ventilation tower in dense urban areas Part 1, J ournal of Environomental Engineering (Transactions of AlJ ), Vol.82, N 0.731, pp.43-50, 2017.1 (In J apanese)

滝澤正玄，倉㴊隆，鳴海大典，ほか 2 名: 密集市街地における換気塔を利用 した通風・換気促進に関する研究 第 1 報」，日本建築学会環境系論文集， 第 82 巻，第 731 号，pp.43-50, 2017.1

169) Kobayashi, T. : Researches on Ventilation Mechanics and A irflow A nalysis for Natural and Cross Ventilation of Buildings, Proc. of the 25th AlJ Air Symposium, pp.25-36, 2016.8 (In J apanese)

170) K obayashi, T. : A review of A cademic Research on Building Ventilation in Japan and an Example of Current Work, Proc. of the Research Conference of Environ. Eng. Society of SHASE Kinki Chapter, N 0.331, pp.13-24, 2017.12 (In Japanese) 


\title{
130 YEAR HISTORY OF BUILDING NATURAL VENTILATION RESEARCH IN JAPAN \\ - A NARRATIVE REVIEW
}

\author{
Tomohiro KOBAYASHI ${ }^{* 1}$ \\ ${ }^{* 1}$ Assoc. Prof., Division of Global Arch., Grad. School of Eng., Osaka Univ., Dr.Eng.
}

\section{Introduction}

In Japan, building ventilation has historically been regarded as important, and its scientific research has relatively long history as well. Consequently, a large amount of knowledge has been accumulated in the research field to date. However, there are few literatures that organized the history of the scientific progress in ventilation research, which can cause a difficulty in discovering the issues and problems to be solved for scientists in this research field. Therefore, this paper reviews the literatures on building ventilation that have been published mainly in Japan of which ventilation research history can be found in architectural engineering, aiming to facilitate understanding of development and to help researchers contemplate the future work.

\section{Beginning of Ventilation Research in Japan and Maturity of the Scientific System}

The scientific research on ventilation was first seen in the 1880s in Japan, and the measurement of natural ventilation rate using tracer gas was conducted by leading researchers who had learned in Germany. Ever since that time, it had been studied mainly as a part of public health until the 1920s. A fter that, many researchers in the building science also came to be involved in the building ventilation research, and many papers could also be seen in the AIJ transaction which started in 1936. In the early 1960s, the calculation method such as flow network model were developed, while materials for calculation like $\mathrm{C} p$ values and $\mathrm{p}$-Q curves for ventilation devices were organized as well. It is interpreted that the basis of the general theory and strategy regarding building ventilation design and calculation have been founded in the end of the 1960s through the activity of the committee in AlJ.

\section{Progress of Subdivided Ventilation Research Topic in the Contemporary Period}

After the oil crisis in the 1970s, natural ventilation research was focused on considering energy saving. Many works of applied research can be seen in this period especially for residential buildings, and above-mentioned basic theory was utilized for research works. From this period, a wide range of research regarding building ventilation came to be seen in this field. The technique of computational fluid dynamics (CFD) was well studied, and the calculation of the indoor 3-D turbulent flow was first seen in the middle of 1970s, which seemed to be a kind of breakthrough and there appeared many research works using CFD appeared in the 1980s. In this period, the 1980s, the topic of ventilation efficiency was also focused on. Several indices for ventilation efficiency assuming CFD use were proposed as well, and the index for ventilation efficiency has been studied to date. After the 2000s, many research works on natural ventilation for non-residential buildings have also been carried out, especially for high-rise office buildings. It has still not yet been organized systematically, but the knowledge has been accumulated in this field. The cross-ventilation have also been studied by many researchers. Several modelling methods to predict flow rate have been proposed, and fundamental research to understand detailed phenomenon have kept on going.

\section{Summary}

The building ventilation research is interpreted to be a mature research field of which basis has almost been completed in the 1960s. Even after that, remarkable progress has been achieved to date, but in many studies, we are still utilizing a basic system of learning that was founded more than fifty years ago. There seems to be a possibility that we are restricted by a kind of common sense in thinking about research methodologies, which may not be necessary any more. Understanding the details of research progress seems important to discover new challenges in the field. 